\title{
Institutional Transformation Aimed To Support the Farmers Empowerment Strategy in Lumajang Regency
}

\author{
Ignatia Martha Hendrati \\ Faculty of Economics, University of National Development "Veteran", Surabaya, Indonesia
}

\begin{abstract}
This study aims to determine the conditions of farming and institutional in supporting the empowerment of coffee farmers and to formulate strategies for the empowerment of coffee farmers in the Pasrujambe Village, Pasrujambe Subdistrict, Lumajang through institutional reinforcement. This study uses a qualitative approach as the type of descriptive study by using observations and interviews to assess the institutional development of community empowerment efforts. The results show that the conditions of farming community of coffee farmers have three limitations: the ability to enhance the quality and production; the lack of venture capital and the low skill. These three limitations affect the condition of existing institutional farmers' groups and eventually impact on low institutional performance. In order to overcome the limitations, Institutional development strategy is drafted in the empowerment of farmers, expected to be a reference to increasing the ability of independent community of coffee farmers, namely: human resource development strategy in the group of farmers, development of production quality, and reinforcement of capital sources.
\end{abstract}

Keywords: Coffee Farmers, Institutions, Empowerment

\section{Introduction}

Development is essentially a well-planned change to be something better. In other words, development is a process of change towards a better life. At first, the development process is focused more on economic growth and social change as a whole. Development is something of inter-related and integrative process.

Sustainable development process that focuses on the human development approach is closely related to social change movements. The concept of development as a system includes: a) input, which consists of values, human resources, natural, cultural and community institutions; b) process, organizational capabilities, and management of government in implementing development programs; c) output, an increasing standard of living.

Development of plantation estates, especially agriculture, aimed at increasing production and incomes of farmers. Targets to be achieved in plantation estates development is formulated in the Tri Dharma Estates, namely: 1) increasing production, quality and type of materials and industrial raw materials exports to increase foreign exchange income, 2) the fulfillment of industrial materials as well as the creation and income generation, and 3) equal employment opportunities to achieve equitable distribution of income (Directorate General of Plantation Estates, 2007)

Plantation business in Indonesia is generally done as people's plantation business which have the characteristics: 1) low productivity per unit area, 2) lack of capital, 3) lack in implementing technical culture, resulting in low production and farmers' income (RI Department of Information, 2007). This is compounded by the necessities of life that can not be postponed, so that farmers have to sell their production before the harvest time.This also happens in the business area of coffee plantations in Lumajang, East Java. Farmers prefer to pick and sell the coffee before the harvest time; this is due to being pressured by the daily needs. This habit is a major obstacle in realizing the Tri Dharma Estates, as already announced by the government as the objectives of agricultural development. Therefore, it is required to have empowerment of farmers in an effort to achieve it. Institutional farmers also have not optimally run.

There are two ways of how institutions formed, naturally or through engineering. The first occurred in the principal institutions and seemed to grow naturally (crescive institution), while the latter is because of the perceived (enacted institution).

A naturally formed institution is starting from the maturation of a norm. The norm will be formed in stages ranging from how to behave, increased to a habit, a code of conduct, and finally it becomes a custom. A norm is said to have been institutionalized if recognized, known, or understood, adhered to, and appreciated, until there is a process of internalization. While Institutional form through engineering is starting from building the structure first, which is common in institutional introduced from outsider, for example, farmer groups and "Koperasi" (an economic enterprise).

The role of economic institutions specifically for the Pasrujambe Village, Pasrujambe District Lumajang is not optimal, just being the complement of the project. This causes farmers to be difficult to access capital assistance from the government or existing financial institutions; the farmers will eventually depend on the middlemen. 


\section{Problems to Discuss:}

Based on the the background of the study above, the problems to discuss of this study are:

1. What is the condition of farmers and their institutional conditions to support the empowerment of farmers in the village of Pasrujambe, Pasrujambe District Lumajang?

2. How is the strategy of independent coffee farmers institutional development in the village of Pasrujambe, Pasrujambe District Lumajang?

\section{Research Objectives:}

1. To determine the condition of coffee farmers in the village of Pasrujambe, Pasrujambe Subdistrict, Lumajang Regency.

2. To determine the condition of institutions in supporting the empowerment of farmers in the village of Pasrujambe, Pasrujambe Subdistrict, Lumajang Regency.

3. To formulate a strategy to empower independent coffee farmers in the village of Pasrujambe, Pasrujambe Subdistrict, Lumajang Regency through an institutional reinforcement.

\section{Social Capital}

\section{Literature Review}

The experts' opinion in defining the concept of social capital can be categorized into two groups. The first group emphasizes the network of social relationships (social network), while the second group emphasizes more on the characteristics (traits) that are attached to the individual human being engaged in a social interaction.

The first group emphasizes the network aspects of social relations that are bound by the ownership of information, trust, mutual understanding and common values, and mutual support. According to this group, social capital will be even stronger if a community or organization has a network of cooperative relationships, both internally within community/organization, or partnership that is inter-community/organization. Definition of the second group points out that social capital is seen as a nature (trait) that attached to (embedded) in the form of life values and rules adopted and executed by individuals who facilitate good cooperation.

In essence the human relationships are a central (relationship matter). Humans will never live, work independently, and always need each other, so they will work together to achieve their goals. Since the goal could be obtained by working alone, but it requires a great sacrifice or greater cost. So that working together could reduce transaction costs or expenses to get information.

\section{Basic Elements of Social Capital}

Basic study of social capital lies in how the ability of communities established an entity or group of cooperation in a network. Partnership or relationship is being regulated by the pattern of reciprocal interrelationship and mutual benefit, based on the values and norms, and built on a foundation of trust.

\section{a. Values}

Values are abstract and exist in the form of thought or reason, but the value can be inferred and interpreted from the words, behaviors, generated actions, so that speech, behavior, and actions generated by the subject is the manifestation of value. Because social capital is largely determined by the configuration of the value created in society; it is then for people who appreciate the values of honesty, justice, togetherness, achievement, so that the existence of society would be far more developed than people who do not appreciate those values.

\section{b. Norms}

In order to control the behavior developed in the community, the social norms will be much involved, it is then between the values and norms are always hand in hand. The norm itself is a set of rules that are expected to be obeyed and followed by members of the public in a particular social entity (Hasbullah, 2006: 13). Usually institutionalized norms and social sanctions can prevent an individual to do something aberrant prevailing in society.

c. Trust

Trust can be defined as belief, confidence or faith as well. Trust is a relationship between two or more parties that contain favorable expectations of one or both sides through social interaction. In the view of Fukuyama $(1995,1997)$ trust is a mutual community trust in each other that allows society to be united with others and contribute to the enhancement of social capital. Collective actions based on mutual high trust will increase the "participation" of society.

\section{d. Networking}

Social capital is not built only by a single individual, but rather lies in the tendency growing within group to socialize as an important part of the inherent values. Social capital will strongly depend on the capacity of existing community groups to build a number of the following associations to build its network. Network is the 
bond between nodes (individuals or groups) that associated with the media (social relations). Social relations are bound by the trust, may be in the form of strategic, also in the form of moralistic. Trust is maintained by the norms that bind both parties in the form of participation in existing networks.

\section{Research Type}

\section{Methods}

This study is a qualitative descriptive study, using observation and interviews with informants who are considered to know and understand the objects studied. Researchers gather in-depth information about the state of farming and institutional coffee farmers' empowerment in the Pasrujambe village, Pasrujambe Subdistrict, Lumajang Regency.

\section{Data}

This study uses primary data and secondary data. Primary data were obtained through in-depth interviews to gather information about research problems. Research Informant is the mayor of Pasrujambe, Pasrujambe Subdistrict, Lumajang, while the casual informants consist of six (6) coffee farmers who are actively involved in farmer groups. Researchers use an observation to directly observe objects so as to obtain an overview of research activities related to the life of the coffee farmers communities.

While the secondary data includes data from BPS (Central Department of Statistics) and the Potency of the village area including the capacious of territory, population, level of education and employment, and also data from Bappeda (Department of Regional Development) and the Department of Agriculture and Plantations related to the government program on farmers and coffee plantations.

The data in this study were collected by using several methods: First, unstructured interviews and indepth interviews. Second, participatipated observation as a data collection method used to collect research data through observation and sensing (Bungin, 2007: 115).

Qualitative research can be doubtful for several reasons, therefore the most important and easiest way to test the validity of the research is to do a triangulation of researchers, methods, theories, and data sources.

Data were analyzed in a qualitative study to describe the research reports that contain excerpts both from the results of observation and in-depth interviews and the result of interviews is included in the description to support the description of the field more clearly. Further descriptive analysis techniques are used to look at any factors that influence the institutional development of coffee farmers' communities in the Pasrujambe village, Pasrujambe Subdistrict, Lumajang Regency and subsequently analyzed descriptively according to empirical data in the field.

\section{Scopes of the Study}

The focus of this research is the interaction between the individuals involved in the group, in an effort to empower farmers so that they can formulate a strategy of coffee farmers empowering in the village of Pasrujambe, Pasrujambe Subdistrict, Lumajang Regency, through institutional strengthening independently.

\section{Result and Discussion}

Pasrujambe village is one of the seven villages in the Subdistrict of Pasrujambe Lumajang with the area of $43.89 \mathrm{~km}^{2}$. The village locates $\pm 10 \mathrm{~km}$ south-west district Candipuro, Lumajang, East Java, or $\pm 40 \mathrm{~km}$ west southwest of the city of Lumajang. The rainfall for this region on average per year is $952 \mathrm{~mm}$ with the number of rainy days is 220 days per year.

The population of the Pasrujambe village is 12,078 people, spreading in 11 small villages. Livelihoods of most of population are farmers with its main commodities are coffee with a shade of banana plants. Farmers do plantation and expansion of coffee crops in the former location of deforestation in the eastern slopes of Mount Semeru.

\section{Plantation Estates Condition}

Of all the coffee plantations owned by farmers in the village of Pasrujambe, averagely obtained from generation to generation are from using shaded banana plants, where its presence could make the competition for the coffee plant nutrients because farmers do not make the arrangement of the farm. On the other hand, banana plants can produce a sizable extra income while experiencing the downturn in coffee prices.

The area of coffee plantations in the region is approximately 100 acres, with a kind of coffee of robusta. But of the 100 acres of coffee plantations, the productivity of the coffee farmers are around 0.5 to 1.0 $\mathrm{kg} / \mathrm{ph}$ or $500 \mathrm{~kg} / \mathrm{ha}$. The low productivity is due to the mixed farms, their fields, such as banana plants, sengon, mangosteen, coconut, langsep and durian. The mixed farmers earned income ranges from Rp. 2.5 million/ha. 
The gegraphical location of Pasrujambe village on the slopes of Mount Semeru also affect towards the low productivity. Activity of Semeru Mountain often causes volcano ash and unfavorable climatic conditions, resulting in failure of fertilization of coffee plants.

\section{Farmers Condition}

Many farmer groups formed along with the development of Lumajang Regency, and is still not formed by plants that are managed specifically. Farmer groups are located in a region of Primatani, founded since June 2005. In Lumajang district there are 12 farmers' groups, the number is very low for a district that has a wide land area of coffee plantations. The production of coffee plantations in 2006 were 3,005 tons and for 2009, the total are 3,140 tons. While the coffee plantation area consists of Immature plants (TBM) covering an area of 452 ha, production Plants (TM) covering an area of 3,904 ha and Generating Plant, an area (TTM) of 851 ha (Source Data: Plantation Statistics 2009-2011, Ministry of Directorate-General of Agriculture and Plantation)

\section{Coffee Institutions Condition}

Farmers' Institutions such as found in areas of Lumajang have been developed, but its development was perceived as a complement project, not as a whole community empowerment. As a result, its performance is less encouraging, even its existence is not sustainable. It can be seen that some farmers are still passive, the existence and activities are virtually non-existent. Even if there is an activity, it is still very limited. Therefore, the failure of development in the agricultural sector which is generally encountered in each region happened because of the unprepared farmers in the level of farmers' organizations in carrying out these functions. The Function of farmer groups is not maximized in terms of limitations: 1) the ability to enhance the quality and production, 2) the adequacy capital in the business, and 3) low skills.

The majority of residents in the Pasrujambe village are Java community that upholds the values of local wisdom "ngunduh wohing pakarti" means that Javanese understand, realize and believe that "sing nandur becik bakal becik undhuh-undhuhane, sing nandur ala akal ala undhuh undhuhane," which means who grow good fruit surely will grow goodness, who grow bad fruit surely will grow ugliness (Haq, 2011). Fundamental values upheld here are: 1) the pillars, the goal are to maintain a harmonious society, harmony, peaceful and quiet without strife (Geertz, 1983). The Javanese have to be "ngelli", should not disrupt the social balance of the interests and personal ambitions. 2) The value of respect, this view is expecting a well ordered society, where everyone knows the place and their respective duties.

Based on the existing local culture, it is not hard to develop the institutional pillars of wisdom with local farmers. Values of harmony and respect are a positive value that can be developed so as to strengthen the institutional coffee farmers that have been established. With the awakening of awareness of farmers, it is expected that farmers are able to act as a strong and independent groups.

\section{Institutions Development Strategies}

In order to empower the farmer groups in the village of Pasrujambe in achieving the goals, it is needed to set a policy of strategy in the hope in obtaining a solution to empower farmers to the maximum so the level of rural poverty will be changed to an economic independence. There are three components to be developed as a strategy for institutional development of independent farmers in the village of Pasrujambe, namely:

\section{a. Human Resource Development Strategies of Farmers}

Farmer groups as a forum for farmers gathering is important to ensure the number of farmers, land area, and cultivated species. It is very easy for the farmer groups to have a role in coaching, counseling, seed selection, fertilizer plants and drugs, controlling, and managing the quality of production and marketing.

One important factor for the realization of effective farmers' groups is the leadership of the chairman of the farmer groups. Chairman of the group can be viewed as the primary agent for an effective group, because of its strategic role in affecting or moving the members of the group to achieve the objectives of the group or its members.

Teamwork within groups is built on trust, which is not created mechanically or spontaneously, but the trust arising from a reciprocal relationship, through the fulfillment of rights and responsibilities of each other. This is a form of social capital because then the values are expected to be achieved include: (a) the value of "harmonization"; (b) the value of commitment and responsibility so that the group will be sustainable (c) the value of honesty; (d) the value of togetherness in the planning, evaluating and expecting to act collectively in accordance with a joint decision, (e) the value of honor and respect of the opinions of others in the discussion; (f) values for a harmonious relationship with the economic improvement; and (g) the value of fairness in the distribution of information. 


\section{b. Quality and Production Development Strategies}

Strategy in the development production and quality is better and sustainable, as described in the following three areas: (a) changing the orientation of farming, (b) an increase in cultivation technology (c) developing entrepreneurial orientation. Changing the orientation of the farm means that the group will be developed by culture of "petik merah" which means that the system of "debt bondage" which is always run by middleman will be abandoned. Post-harvest processing using wet process to improve the coffee quality.

In this case, the improvement of cultivation technology is that if the previous agro-forestry coffee plantations are irregular, it turned into a healthy farming production that is expected to be optimum. However, natural factors will be a factor that cannot be controlled; it is because Pasrujambe village is located on the slopes of Mount Semeru. Frequently ash occured could result in a failure of fertilization. This can be anticipated by the selection of variety which would be last long in a climate change.

Development of entrepreneurial orientation is an effort developed to bridge the harvest time; all of refined products can be developed as a source of farmers income. They can take advantage of shade plants, such as banana, ginger or coffee that can be processed into ready-consumed products. Thus there will be continuity in farmers' income outside of coffee farming.

\section{c. Reinforcement Strategies of Capital Resource}

The strategy of the capital resources development in the rural community of Pasrujambe coffee farmers should be developed through the group: 1) the capital itself, ie by optimizing the capital of each farmer, 2) capital partners, namely optimizing capital revolving fund for agricultural business; 3) external capital, which facilitates the farmer members to access capital from financial institutions and government programs.

\section{Conclusions and Recommendations}

\section{Conclusions}

Coffee farming in the village of Pasrujambe, Pasrujambe Subdistrict, Lumajang Regency has low productivity, in terms of both quality and quantity. This is because of the unsophisticated and irregular cultivation technology of coffee plantations, as a result of cultivation techniques which was built for generations and by harvesting the corp plunderly. In addition, since the location of Pasrujambe village is on the slopes of Mount Semeru, natural factors also affect the low productivity. Frequent ash and unfavorable climate also inhibits fertilization of coffee plants.

The coffee farmers in an institutional level, in the Pasrujambe village Pasrujambe Subdistrict are not optimally running, so its performance is not up to the expectations to improve the welfare of farmers. But with the rooted of local values wisdom, it is most likely to develop a strong and independent institutional of coffee farmers.

Strategies to empower coffee farmers independently in the Pasrujambe village, Pasrujambe Subdistrict, Lumajang Regency through the development of: 1) human resources in the level of farmers, 2) quality and production, and 3) reinforcement of capital sources.

\section{Recommendations}

For the people, especially farmers, it is needed to put more effort to optimize its ability by fostering motivation and creativity to entrepreneurship that will result in continuity of farmers' income. In addition, farmers should be widely open in dealing with any changes so that coffee farming can be more productive and their welfare will increase.

Based on these results, it is expected that the government, in this case the Department of Agriculture and Plantation, can make an empowerment program for coffee farmers' community, with a foothold on the local characteristics of the society. Assistance and capacity building of farmers have to be continuously strived to create productive and prosperous coffee farmers.

\section{References}

[1] Anonim. 2009. Peraturan Gubernur Jawa Timur Nomor 7 Tahun 2009. Diundangkan dalam Berita Daerah Provinsi Jawa Timur Tanggal 5 Februari 2009 No. 7 Tahun 2009/E1. Dok. Informasi Hukum -JDIH Biro Hukum Setda Prov Jatim

[2] Arai, Kazuhiro. 2007. Trust and Trustworthiness in the Economy: How They Function and How They Should Be Promoted. Hitotsubashi Journal of Economics,48(2):225-240. (http://hermes ir.lib.hitu.ac.jp/rs/bitstream/10086/1515/1/HJeco0480202250.pdf, diakses 22 Juli 2010)

[3] Bungin, Burhan. 2007. Penelitian Kualitatif: Komunikasi, Ekonomi, Kebijakan Publik, dan Ilmu Sosial Lainnya. Jakarta : Kencana

[4] Cohen, D. Prusak, L. 2001. In Good Company, Boston: Harvard Business School Press

[5] Coleman, J.S. 1990. Foundations of Social Theory. Cambridge: Harvard University Press.

[6] Fukuyama, F. 1995. Trust: The Social Virtues and the Creation of Prosperity. London: Hamish Hamilton.

[7] 1997. Social Capital and The Modern Capitalist Economy: Creating a High Trust Workplace. Stern Business Magazine, Vol 4. no 1.

[8] Geertz, H. 1983. Keluarga Jawa, (Terjemahan). Grafiti Pers, Jakarta

[9] Hasbullah, Jousairi. 2006. Social Capital (Menuju Keunggulan Budaya Manusia Indonesia). Jakarta : MR-United Press 
[10] Hikmat, Harry. 2004. Strategi Pemberdayaan Masyarakat. Humaniora Utama Press, Bandung

[11] Kaahiruddin.2000. Pembangunan Masyarakat Tinjauan Aspek : Sosiologi, Ekonomi dan Perencanaan. Cetakan kedua : Liberty. Yogyakarta

[12] Moleong, Lexxy J. 2006. Metodologi Penelitian Kualitatif. Bandung : Rosda

[13] Mubyarto 1989. Pengantar Ekonomi Pertanian. Jakarta : Edisi Ke-tiga, LP3S

[14] Mulyana, Deddy. 2001. Metodologi Penelitian Kualitatif. Bandung: Penerbit PT. Remaja Rosdakarya.

[15] Quibria, M. G. 2003. The Puzzle of Social Capital A Critical Review. Asian Development Review, vol. 20, no. 2, 19-39

[16] Roumasset, J. 2004. "Rural Institutions, Agricultural Development and Pro-Poor Economic Growth." Asian Journal of Agriculture and Development 1(1):56-75.

[17] The World Bank .1999. What is Social Capital?, PovertyNet http://www.worldbank.org/poverty/sca pital/whatsc.htm

[18] Yustika, Ahmad Erani. 2006. Ekonomi Kelembagaan : Definisi, Teori, dan Strategi. Malang : Bayumedia 